\title{
THE QUEEN'S UNIVERSITY OF BELFAST
}

\section{LECTURER IN GEOLOGY}

Applications are invited for a LeCtUREShIP IN GeOLOGY. The salary offered is $£ 500$ per annum, rising by increments of $£^{25}$ to $£ 625$ with possible further increments to a maximum of $£ 800$. The successful candidate will be required to become a member of the F.S.S.U. if he is not already a member; he will be expected to take up duty on 1st October, 1946, but if he is on approved national service he may be allowed to defer doing so until released from such duties. Ten copies of applications should reach the undersigned before 1st June, 1946. Further particulars may be had from

\section{RICHARD H. HUNTER,} Secretary.

GEOlogist. Aircraft Operating Co., of Africa (Pty.), LTD., offers APPOINTMENT to an experienced Geologist in Africa. Geological mapping experience, airphoto geology and prospecting experience essential. Appointment would be temporary at first for one specific operation, but might be made permanent. Write, stating age, availability, academic qualifications and professional experience to

Hunting Aerosurveys, Ltd., 29 Old Bond Street, London.

\section{The Geological Magazine}

Bound volumes are better than loose parts. Send your Geological Magazine to be bound in attractive green cloth covers, 6s. (postage 7d. extra); cloth cases only, 3s. (postage 3d. extra).

STEPHEN AUSTIN \& SONS, LTD. 1 FORE STREET, HERTFORD 